\title{
Impact of Consumer Loans on Inflation and Current Account Deficit: A Toda Yamamoto Causality Test for Turkey ${ }^{1}$
}

\author{
Serhat Yüksel ${ }^{2}$ and Mustafa Özsari ${ }^{3}$ \\ Received: 11/07/2016; Revised: 29/10/2016; Accepted: 01/11/2016
}

\begin{abstract}
This study aims to investigate the causality relationship between consumer loans and inflation, and consumer loans and current account deficit in Turkey. In this scope, Toda Yamamoto causality test is used for the periods between 1994:1 and 2015:3. According to test results, we found that there is no causal relationship between consumer loans and inflation rate, and consumer loans and current account deficit. In other words, changes in consumer loans do not lead neither high current account deficit rates nor high inflation rates in Turkey. Therefore, limiting consumer loans is not the solution for inflation and current account deficit problems of Turkey and policy makers should apply some other effective policies to solve high CA deficit and high inflation problems.
\end{abstract}

Keywords: Consumer Loans, Inflation, Current Account Deficit, Toda Yamamoto Causality Test

JEL Codes: E31, E51, F32

\footnotetext{
${ }^{1}$ Turkish version of this paper was presented in Econworld London Conference.

2 Corresponding Author, School of Business, İstanbul Medipol University, İstanbul, Turkey. serhatyuksel@medipol.edu.tr

Department of Economics, Konya Food and Agriculture University, Konya, Turkey. $\underline{\text { mustafa.ozsari@gidatarim.edu.tr }}$
} 


\section{Introduction}

The amount of consumer loans in Turkey increased very much in recent years, due to the decrease in interest rates (Dücan et. al., 2016). This increase affects economic growth of the country positively because of increase in the amount of consumption (Mercan, 2013). It was also accepted that increase in consumer loans causes some problems, such as higher inflation rate (Arsene and Guy-Paulin, 2013). The main reason behind the inflationary effect of consumer loans is that the loans cause a shift in the consumption amount, and that shift leads to higher inflation rates. In other words, higher loans allow people to increase their consumption level and their demand for goods and services which leads the prices of goods and services to increase as well.

Current account deficit is another problem that may be caused by higher consumer loans (Tiryaki, 2014). If consumer loans lead to increase in the consumption of the imported goods and services more than domestic goods and services, this will affect the current account balance of the countries negatively. In other words, an increase in the demand for imports may cause current account deficit to increase. This is an important problem for a country because if the ratio of current account deficit to GDP exceeds 5\%, it is accepted as an early signal for an economic crisis (Yüksel, 2016).

Higher inflation increases uncertainty in the market, and the economy becomes more fragile (Kessel and Alchian, 1962). Current account deficit is also significant for the overall economy because of the balance of payments. Therefore, these economic variables should be analyzed continuously to manage the problems effectively. Ergo, studies related to these variables present important results for policy makers.

In this study, we tried to identify whether there is a causality relationship between consumer loans and inflation rate, and consumer loans and current account deficit in Turkey. We used Toda Yamamoto causality test for the periods between 1994:1 and 2015:3 to achieve this objective.

The paper is organized as follows. After introduction part, we give information about similar studies in the literature. In the third part, the development of consumer loans in Turkey will be emphasized. The fourth part includes research and application to understand the relationship between consumer loans with inflation rate and current account deficit in Turkey. Conclusion part presents the results and the discussion part.

\section{Literature Review}

Consumer loans, inflation and current account deficit are the subjects examined in many studies in the literature. Some of them are emphasized on table 1.

Table 1 shows that most of the studies are related to the relationship between bank loans and current account deficit problem. Hoshi and others (1991) analyzed this relationship in Japan. As a result of the regression analysis, there is a positive relationship between bank loans and current account deficit. Also, Motonishi and Yoshikawa (1999), Kunieda and Shibata (2005), Biztis and others (2008), Telatar (2011), Göçer and others (2013), Kılıç (2015), Morel Benito and Roehn (2016), Dücan and others (2016), Davis and others (2016) and Akçayır and Albeni (2016) reached equivalent results in their studies. On the contrary, Begeç (2015) concluded that loan amount does not have any effect on current account deficit by using Johansen co-integration analysis. 
Table 1: Similar Studies in the Literature

\begin{tabular}{|c|c|c|c|}
\hline Author & Method & Scope & Result \\
\hline $\begin{array}{l}\text { Hoshi et. al. } \\
(1991)\end{array}$ & Regression & Japan & $\begin{array}{l}\text { There is a positive relationship between loan } \\
\text { amount and current account deficit. }\end{array}$ \\
\hline $\begin{array}{l}\text { Motonishi and } \\
\text { Yoshikawa } \\
\text { (1999) }\end{array}$ & Regression & Japan & $\begin{array}{l}\text { Policies that limit loan usage are effective to } \\
\text { decrease current account deficit. }\end{array}$ \\
\hline Groen (2001) & VECM & $\begin{array}{l}\text { Holland } \\
\text { and US }\end{array}$ & $\begin{array}{l}\text { Increase in bank loans leads to higher inflation } \\
\text { rate. }\end{array}$ \\
\hline $\begin{array}{l}\text { Boyd et. al. } \\
\quad(2001)\end{array}$ & Regression & $\begin{array}{c}65 \\
\text { different } \\
\text { countries }\end{array}$ & Higher inflation affects bank loans negatively. \\
\hline $\begin{array}{l}\text { Alper et. al. } \\
\text { (2001) }\end{array}$ & Regression & Turkey & $\begin{array}{l}\text { Higher inflation decreases the usage of the } \\
\text { loans. }\end{array}$ \\
\hline Tang (2001) & VECM & Malaysia & $\begin{array}{l}\text { There is not a relationship between inflation and } \\
\text { loans. }\end{array}$ \\
\hline Bikker (2004) & $\begin{array}{l}\text { Panel Data } \\
\text { Analysis }\end{array}$ & $\begin{array}{l}26 \text { OECD } \\
\text { countries }\end{array}$ & $\begin{array}{l}\text { There is a strong relationship between loans and } \\
\text { inflation rate. }\end{array}$ \\
\hline $\begin{array}{c}\text { Kaya and } \\
\text { Doğan (2005) }\end{array}$ & $\begin{array}{c}\text { Data } \\
\text { Envelopment } \\
\text { Analysis } \\
\end{array}$ & Turkey & $\begin{array}{l}\text { Decrease in inflation rate leads to increase in } \\
\text { loans amount. }\end{array}$ \\
\hline $\begin{array}{c}\text { Kunieda and } \\
\text { Shibata (2005) }\end{array}$ & GMM & US & $\begin{array}{l}\text { Increase in the amount of the loans causes } \\
\text { current account deficit problem. }\end{array}$ \\
\hline $\begin{array}{c}\text { Calza and } \\
\text { Sousa }(2006)\end{array}$ & VAR & $\begin{array}{c}\text { European } \\
\text { Union }\end{array}$ & $\begin{array}{l}\text { There is a relationship between loans and } \\
\text { inflation. }\end{array}$ \\
\hline $\begin{array}{l}\text { Eslamloueyan } \\
\text { and Darvishi } \\
\text { (2007) }\end{array}$ & $\begin{array}{l}\text { Bound Test } \\
\text { Approach }\end{array}$ & Iran & $\begin{array}{l}\text { There is a long - term relationship between } \\
\text { inflation rate and loans. }\end{array}$ \\
\hline Haight (2007) & $\begin{array}{l}\text { Descriptive } \\
\text { Statistics }\end{array}$ & US & $\begin{array}{l}\text { Lower inflation rate increases the demand for } \\
\text { loans. }\end{array}$ \\
\hline $\begin{array}{l}\text { Biztis et. al. } \\
\quad(2008)\end{array}$ & $\begin{array}{c}\text { Johansen Co- } \\
\text { integration } \\
\text { Analysis }\end{array}$ & Greece & $\begin{array}{l}\text { Increase in the loans amount causes current } \\
\text { account deficit problem. }\end{array}$ \\
\hline $\begin{array}{l}\text { Arslan and } \\
\text { Yaprakl1 } \\
\text { (2008) }\end{array}$ & VECM & Turkey & $\begin{array}{l}\text { There is a positive relationship between bank } \\
\text { loans and inflation rate. }\end{array}$ \\
\hline $\begin{array}{l}\text { Atta-Mensah } \\
\text { and Din } \\
\text { (2008) }\end{array}$ & $\begin{array}{l}\text { Descriptive } \\
\text { Statistics }\end{array}$ & Canada & $\begin{array}{l}\text { Increase in the amount of bank loans leads to } \\
\text { higher inflation. }\end{array}$ \\
\hline $\begin{array}{c}\text { Ziramba } \\
(2008)\end{array}$ & VECM & $\begin{array}{l}\text { South } \\
\text { Africa }\end{array}$ & $\begin{array}{l}\text { There is not a relationship between bank loans } \\
\text { and inflation rate. }\end{array}$ \\
\hline $\begin{array}{l}\text { Geanakoplos } \\
\text { and Dubey } \\
(2009)\end{array}$ & $\begin{array}{l}\text { Descriptive } \\
\text { Statistics }\end{array}$ & $\begin{array}{c}\text { Literature } \\
\text { Review }\end{array}$ & Credit card usage increases inflation rate. \\
\hline $\begin{array}{c}\text { Bilgin and } \\
\text { Kartal (2009) }\end{array}$ & $\begin{array}{l}\text { Descriptive } \\
\text { Statistics }\end{array}$ & Turkey & $\begin{array}{l}\text { The policies aimed to lower inflation rate leads } \\
\text { to increase bank loans. }\end{array}$ \\
\hline $\begin{array}{l}\text { Hülsewig et. } \\
\text { al. (2009) }\end{array}$ & $\begin{array}{l}\text { Descriptive } \\
\text { Statistics }\end{array}$ & Euro Area & Prices of the goods are affected by the loans. \\
\hline $\begin{array}{l}\text { Huy Vu } \\
(2010)\end{array}$ & $\begin{array}{l}\text { Panel Data } \\
\text { Analysis }\end{array}$ & $\begin{array}{c}\text { Denmark, } \\
\text { Norway } \\
\text { and } \\
\text { Sweden } \\
\end{array}$ & $\begin{array}{l}\text { Increase in the amount of the loans causes } \\
\text { higher inflation. }\end{array}$ \\
\hline $\begin{array}{l}\text { Akinboade and } \\
\text { Makina (2010) }\end{array}$ & VAR & $\begin{array}{l}\text { South } \\
\text { Africa }\end{array}$ & $\begin{array}{l}\text { It was determined that bank loans do not have } \\
\text { any effect on inflation. }\end{array}$ \\
\hline
\end{tabular}




\begin{tabular}{|c|c|c|c|}
\hline Telatar (2011) & $\begin{array}{l}\text { Granger } \\
\text { Causality } \\
\text { Analysis }\end{array}$ & Turkey & $\begin{array}{l}\text { There is a causality relationship between } \\
\text { consumer loans and current account deficit. }\end{array}$ \\
\hline $\begin{array}{l}\text { Moinescu } \\
(2012)\end{array}$ & $\begin{array}{l}\text { Panel Data } \\
\text { Analysis }\end{array}$ & $\begin{array}{l}\text { European } \\
\text { Union }\end{array}$ & $\begin{array}{l}\text { Consumer loans have an increasing effect on } \\
\text { inflation rate. }\end{array}$ \\
\hline Asongu (2012) & Regression & $\begin{array}{l}34 \text { African } \\
\text { countries }\end{array}$ & $\begin{array}{l}\text { It was seen that precautions to decrease bank } \\
\text { loans are successful to decrease inflation rate. }\end{array}$ \\
\hline $\begin{array}{l}\text { Gambetti and } \\
\text { Musso (2012) }\end{array}$ & VAR & $\begin{array}{l}\text { UK and } \\
\text { US }\end{array}$ & Amount of the bank loans affects inflation rate. \\
\hline $\begin{array}{l}\text { Göçer et. al. } \\
\text { (2013) }\end{array}$ & $\begin{array}{l}\text { Johansen Co- } \\
\text { integration } \\
\text { Analysis }\end{array}$ & Turkey & $\begin{array}{l}\text { There is a long-term relationship between loans } \\
\text { and current account deficit. }\end{array}$ \\
\hline $\begin{array}{l}\text { Arsene and } \\
\text { Guy-Paulin } \\
\text { (2013) }\end{array}$ & VAR & Cameroon & $\begin{array}{l}\text { It was defined that bank loans increase inflation } \\
\text { rate. }\end{array}$ \\
\hline Tiryaki (2014) & $\begin{array}{c}\text { Granger } \\
\text { Causality } \\
\text { Analysis } \\
\end{array}$ & Turkey & $\begin{array}{l}\text { There is a causality relationship between } \\
\text { inflation and consumer loans. }\end{array}$ \\
\hline $\begin{array}{l}\text { Tinoco- } \\
\text { Zermeño et. al. } \\
\text { (2014) }\end{array}$ & ARDL & Mexico & $\begin{array}{l}\text { Increase in the inflation rate affects the amount } \\
\text { of the bank loans negatively. }\end{array}$ \\
\hline Kılıç (2015) & $\begin{array}{l}\text { Granger } \\
\text { Causality } \\
\text { Analysis }\end{array}$ & Turkey & Consumer loans cause current account deficit. \\
\hline Begeç (2015) & $\begin{array}{l}\text { Johansen Co- } \\
\text { integration } \\
\text { Analysis }\end{array}$ & Turkey & $\begin{array}{l}\text { Bank loans have impact on inflation rate } \\
\text { however, they do not cause current account } \\
\text { deficit. }\end{array}$ \\
\hline $\begin{array}{l}\text { Akinlo and } \\
\text { Oni (2015) }\end{array}$ & VECM & Nigeria & $\begin{array}{l}\text { Lower inflation rate leads to increase in the } \\
\text { amount of the loans. }\end{array}$ \\
\hline $\begin{array}{l}\text { Pool et. al. } \\
\text { (2015) }\end{array}$ & Panel VAR & $\begin{array}{l}12 \text { OECD } \\
\text { countries }\end{array}$ & $\begin{array}{l}\text { Inflation rate does not affect the amount of the } \\
\text { bank loans. }\end{array}$ \\
\hline Kilıç (2015) & $\begin{array}{l}\text { Granger } \\
\text { Causality } \\
\text { Analysis }\end{array}$ & Turkey & $\begin{array}{l}\text { There is a two-way causality relationship } \\
\text { between bank loans and inflation rate. }\end{array}$ \\
\hline $\begin{array}{l}\text { Korkmaz } \\
(2015)\end{array}$ & $\begin{array}{l}\text { Panel Data } \\
\text { Analysis }\end{array}$ & $\begin{array}{c}10 \\
\text { European } \\
\text { countries }\end{array}$ & $\begin{array}{l}\text { Bbank loans do not have any effect on inflation } \\
\text { rate. }\end{array}$ \\
\hline $\begin{array}{l}\text { Morel Benito } \\
\text { and Roehn } \\
(2016)\end{array}$ & $\begin{array}{l}\text { Panel Data } \\
\text { Analysis }\end{array}$ & $\begin{array}{c}31 \\
\text { different } \\
\text { countries }\end{array}$ & $\begin{array}{l}\text { Increase in the amount of bank loans causes } \\
\text { current account deficit problem. }\end{array}$ \\
\hline $\begin{array}{l}\text { Dücan et. al. } \\
\quad \text { (2016) }\end{array}$ & $\begin{array}{c}\text { Granger } \\
\text { Causality } \\
\text { Analysis } \\
\end{array}$ & Turkey & $\begin{array}{l}\text { Consumer loans lead to increase current account } \\
\text { deficit. }\end{array}$ \\
\hline $\begin{array}{l}\text { Davis et. al. } \\
\quad(2016)\end{array}$ & Regression & $\begin{array}{c}35 \\
\text { different } \\
\text { countries } \\
\end{array}$ & $\begin{array}{l}\text { There is a relationship between loans and } \\
\text { current account deficit problem. }\end{array}$ \\
\hline $\begin{array}{c}\text { Akçayır and } \\
\text { Albeni (2016) }\end{array}$ & $\begin{array}{l}\text { Bound Test } \\
\text { Approach }\end{array}$ & Turkey & $\begin{array}{l}\text { There is a two-way causality relationship } \\
\text { between loans and current account deficit. }\end{array}$ \\
\hline $\begin{array}{l}\text { Ngerebo-A } \\
(2016)\end{array}$ & Regression & Nigeria & $\begin{array}{l}\text { It was concluded that higher loans lead to } \\
\text { inflation problem. }\end{array}$ \\
\hline
\end{tabular}

Source: Authors. 
Furthermore, some other studies aimed to determine the relationship between consumer loans and inflation rate. Groen (2001) analyzed the effects of the increase in the amount of bank loans in Holland and US and identified that increase in bank loans leads to higher inflation. Bikker (2004), Eslamloueyan and Darvishi (2007), Arslan and Yaprakl1 (2008), Atta-Mensah and Din (2008), Geanakoplos and Dubey (2009), Huy Vu (2010), Moinescu (2012), Asongu (2012), Gambetti and Musso (2012), Arsene and Guy-Paulin (2013), Begeç (2015), Kılıç (2015) and Ngerebo-A (2016) also reached a similar conclusion by using different methods. In addition to them, Tang (2001) and Ziramba (2008) determined that there is no relationship between bank loans and inflation rate.

Existing literature shows that there are lots of different studies that focused on the relationship between consumer loans with inflation rate and current account deficit. It was also seen that various types of methods were used in those studies to achieve this objective, such as vector error correction method, regression and Granger causality analysis. Therefore, it can be said that there is a need for a study in which a new methodology was used to evaluate this relationship.

\section{Descriptive Statistics}

\subsection{Consumer Loans in Turkey}

Loans can be mainly divided into two categories which are commercial loans and consumer loans. Commercial loans refer to the loans which are used to support companies for their investment. The loans which are taken by consumers to satisfy their personal needs are categorized as consumer loans. According to the disclosure issued by Banking Regulation and Supervision Agency related to uniform chart of accounts, mortgage loans, auto loans, personal loans and credit cards are accepted as consumer loans (BRSA, 2014).

Increase in consumer loans leads consumption to raise in the country. This situation is beneficial for the economy because an increase in aggregate demand leads economy to grow in the short-run. Therefore, consumer loans enhance economic growth. On the other side, high amount of consumer loans may cause some problems for the economy. Because of increasing consumer loans, the demand and prices of goods and services will go up. So, the country may face high inflation problem.

In addition to the inflation problem, consumer loans may cause current account deficit problem in the country as well. If the increasing consumption directed towards import goods, this will affect foreign trade balance of the country in a negative way. If this negative impact results with an increase in the current account deficit intensity in gross domestic product (CA deficit/GDP), the country may face some serious current account balance problems.

\subsection{The Development of Consumer Loans in Turkey}

Especially after the 2001 economic crisis, there was an improvement in Turkish economy especially for rapid growth rates. Interest rates also went down thanks to the continuous growth rates and financial stability. The amount of consumer loans also increased due to decreasing interest rates.

Graph 1 illustrates the amount of consumer loans between 1994 and 2015 period. One can see the increase in the amount of consumer loans since 2003 to 2012. There was a stunning increase in the amount of consumer loans between third quarter of 2012 and second quarter of 2014. The main reason behind the sudden decrease is the actions of Banking Regulation and Supervision Agency to decrease the amount of consumer loans. 


\section{Graph 1: The Developments of Consumer Loans in Turkey}

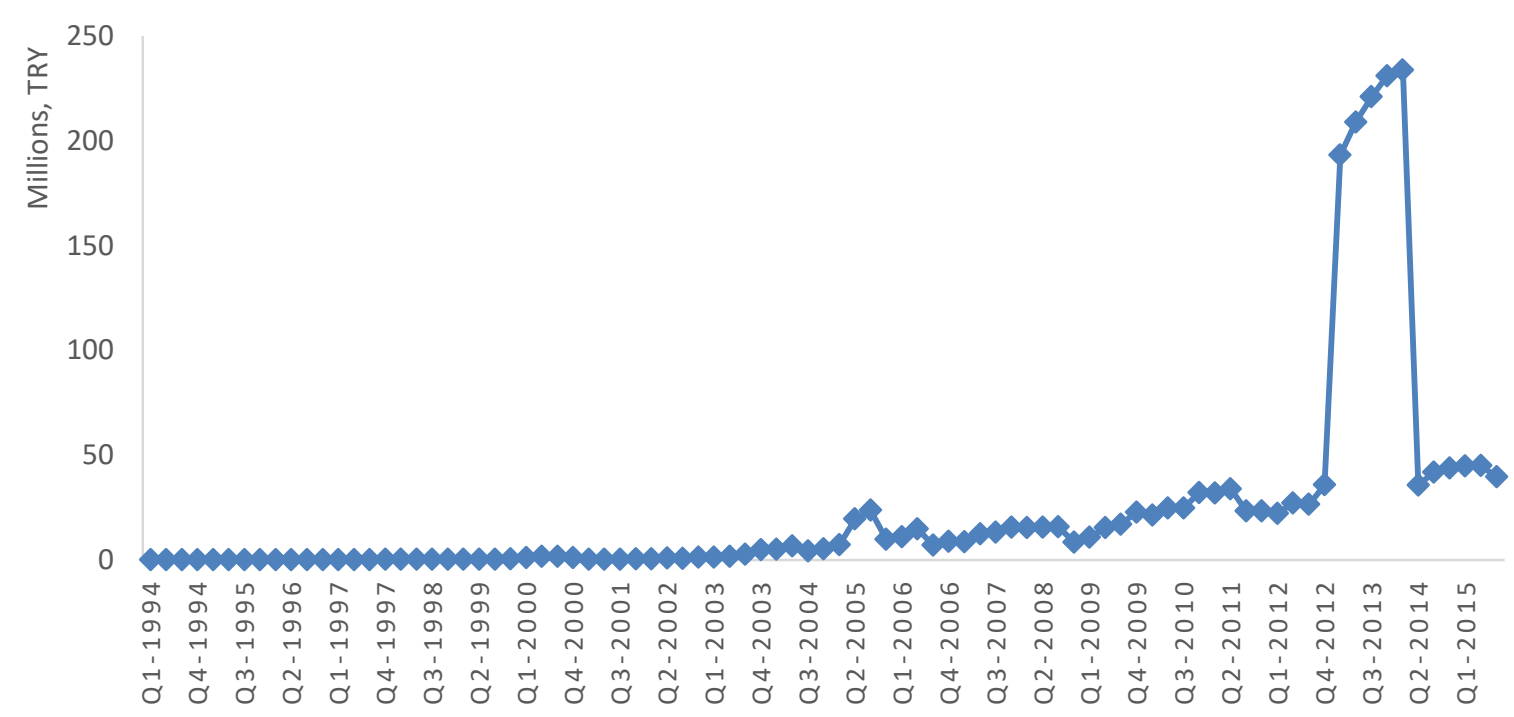

Source: The Bank Association of Turkey

Graph 2 shows the share of automobile, mortgage and personal loans in total consumer loans in Turkey. According to the Graph 2, personal loans have the highest ratio with $69.11 \%$ in consumer loans while mortgage loans have the second highest ratio with $28,17 \%$. Auto loans have the lowest share with $2,72 \%$ in total consumer loans.

\section{Graph 2: Classification of Consumer Loans in 2015}

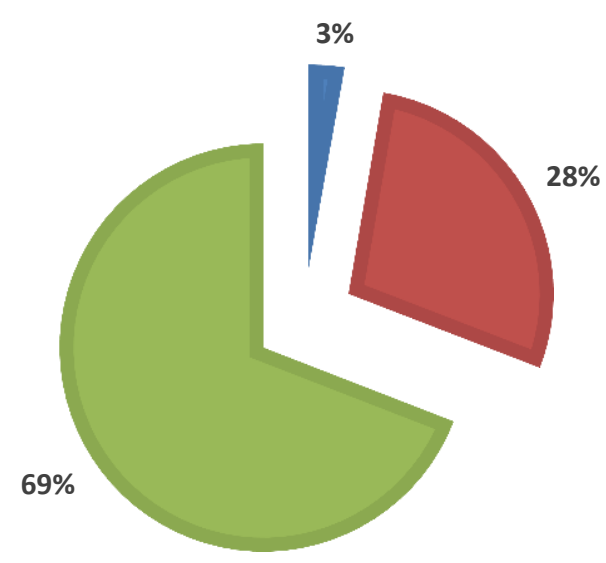

Source: The Bank Association of Turkey

Graph 3 demonstrates the share of consumer loans in total loans. According to Graph 3 , there is an increase in the ratio of consumer loans between 2004-2007 period. One can see that the share of consumer loans in total loans is stable between 2007-2012 period and started to decrease in year 2013. After this year, the ratio of consumer loans started to decrease mainly because of the restrictions implemented by Banking Regulation and Supervision Agency. 
Graph 3: The Ratio of Consumer Loans in Turkish Banking Sector

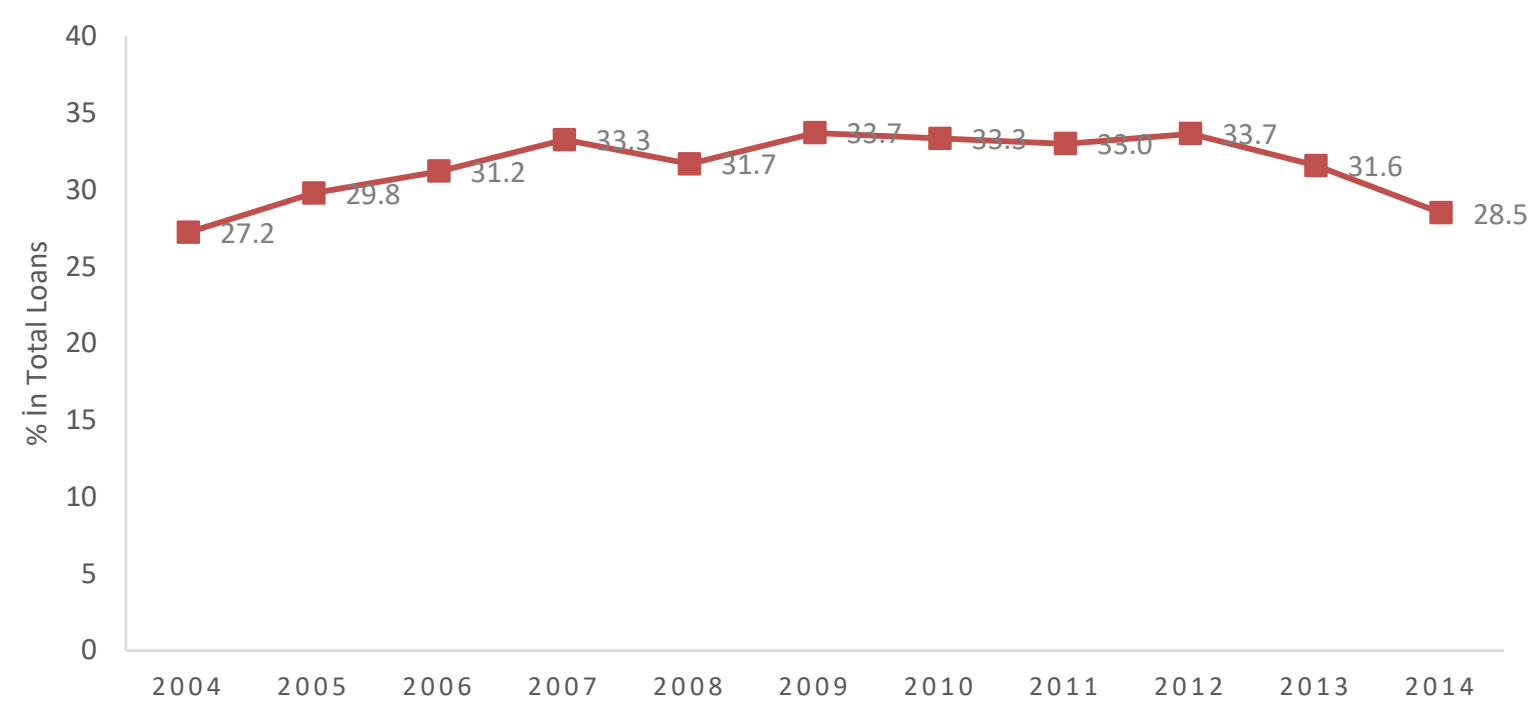

Source: The Bank Association of Turkey

\section{Data and the Analysis}

\subsection{Data Set}

In this study, quarterly data for the periods between 1994:1 and 2015:3 was used. This data was obtained from the websites of Turkish Banking Association and World Bank in 2016. The variable of consumer loans includes installment loans, mortgages, auto loans and credit cards. On the other side, as the inflation rate, changes in consumer price indexes were taken into the consideration. Moreover, the ratio of current account deficit to GDP was used to analyze the risk more effectively.

\subsection{Toda Yamamoto Causality Analysis}

Toda Yamamoto causality analysis also examines whether there is causality relationship between the variables. The main difference of this method from the others is that there is not a requirement for the variables to be stationary. In Toda Yamamoto analysis, maximum degree of integration and lag length in VAR model should be calculated. In other words, if the lag length is " $\mathrm{k}$ " and the maximum co-integration number in VAR model equals to " $\mathrm{d}$ ", this model is estimated with the lag number of " $\mathrm{k}+\mathrm{d}$ " (Toda and Yamamoto, 1995).

\subsection{Analysis Results and Findings}

In this study, first, we made an analysis to define whether the variables are stationary or not. Within this context, Zivot-Andrews unit root test was used. The details of this analysis are given in table 2 .

Table 2 shows that all variables are stationary on their level values. After stationary analysis, appropriate lag lengths of VAR model were calculated and the results are given in Table 3. 
Table 2: Zivot-Andrews Unit Root Test Results

\begin{tabular}{|c|c|}
\hline Variables & Level Value (Probability) \\
\hline Consumer Loans & 0.0009 \\
\hline Current Account Deficit & 0.0457 \\
\hline Inflation Rate & 0.0026 \\
\hline
\end{tabular}

Source: Authors.

Table 3 shows that 5 lag lengths are significant for VAR model. Additionally, according to Zivot-Andrews unit root test results, all variables seem to be stationary at their level values. Hence, the number of maximum co-integration is calculated as 0 . On the other side, as it can be seen in table 3, appropriate lag lengths are defined as 5. As a result, the model should be estimated on 5. (5+0) degree in Toda Yamamoto analysis.

Table 3: Analysis Results to Define Lag Lengths

\begin{tabular}{|c|c|c|c|c|c|c|}
\hline Lag & LogL & LR & FPE & AIC & SC & HQ \\
\hline 0 & -2055.926 & NA & $8.71 \mathrm{e}+18$ & 52.12472 & 52.21470 & 52.16077 \\
\hline 1 & -1830.144 & 428.7017 & $3.60 \mathrm{e}+16$ & 46.63655 & $46.99646^{*}$ & 46.78074 \\
\hline 2 & -1814.314 & 28.85461 & $3.03 \mathrm{e}+16$ & 46.46364 & 47.09349 & $46.71597^{*}$ \\
\hline 3 & -1809.110 & 9.090372 & $3.35 \mathrm{e}+16$ & 46.55974 & 47.45953 & 46.92022 \\
\hline 4 & -1790.987 & 30.28120 & $2.67 \mathrm{e}+16$ & 46.32878 & 47.49851 & 46.79741 \\
\hline 5 & -1778.084 & $20.57963^{*}$ & $2.44 \mathrm{e}+16^{*}$ & $46.22997^{*}$ & 47.66963 & 46.80674 \\
\hline 6 & -1769.775 & 12.62157 & $2.51 \mathrm{e}+16$ & 46.24746 & 47.95706 & 46.93238 \\
\hline 7 & -1764.076 & 8.223863 & $2.78 \mathrm{e}+16$ & 46.33103 & 48.31057 & 47.12409 \\
\hline 8 & -1758.573 & 7.522217 & $3.10 \mathrm{e}+16$ & 46.41957 & 48.66905 & 47.32078 \\
\hline
\end{tabular}

Source: Authors.

The results of this analysis are demonstrated on table 4 . Table 4 shows, $p$ values of all six tests are greater than 0.05 . This means that there is not any relationship between any of the variables in the analysis. In other words, changes in consumer loans do not cause the inflation or current account deficit problems according to Toda Yamamoto causality analysis.

Table 4: Toda Yamamoto Causality Analysis Results

\begin{tabular}{|l|c|c|l|}
\hline \multicolumn{1}{|c|}{ The Way of Causality } & Lag Length & P Value & \multicolumn{1}{c|}{ Result } \\
\hline Consumer Loans $\rightarrow$ Inflation Rate & 5 & 0.8815 & There is no causality relationship. \\
\hline Consumer Loans $\rightarrow$ Current Account Deficit & 5 & 0.7986 & There is no causality relationship. \\
\hline Inflation Rate $\rightarrow$ Consumer Loans & 5 & 0.9724 & There is no causality relationship. \\
\hline Current Account Deficit $\rightarrow$ Consumer Loans & 5 & 0.9888 & There is no causality relationship. \\
\hline Inflation Rate $\rightarrow$ Current Account Deficit & 5 & 0.7483 & There is no causality relationship. \\
\hline Current Account Deficit $\rightarrow$ Inflation Rate & 5 & 0.8315 & There is no causality relationship. \\
\hline
\end{tabular}

Source: Authors. 


\section{Conclusion}

In this study, first we made an analysis to identify whether the determinants of consumer loans, inflation and current account deficit are stationary or not. It was concluded that all 3 variables are stationary on their level values. After that, appropriate lag lengths are defined as 5 and the model is estimated on 5. $(5+0)$ degree in Toda Yamamoto analysis.

The popularity of the topic of consumer loans is increasing in the literature especially in the last years. Because of that, many researchers examined this issue in their studies by using different methods. We used Toda Yamamoto causality test to see if the consumer loans are the reason for higher inflation or current account deficit of Turkey. Our results based on Toda Yamamoto causality analysis showed that consumer loans are not the causation of the problems of high inflation and current account deficit in Turkey. In other words, changes in the amount of consumer loans are not the reason of inflation and current account deficit problems.

It is not possible to say what is the solution to reduce high inflation and the current deficit without conducting more detailed analyses, but limiting consumer loans is certainly not a solution. For the future research, it will be quite beneficial to make analyses about the effects of consumer loans in different countries. 


\section{References}

Akçayır, Ö. ve Albeni, M. (2016). Turkey'de Kredi Genişlemesinin Cari Açığa Etkisi: Sınır Testi Yaklaşımı. Çankırı Karatekin Üniversitesi İktisadi ve İdari Bilimler Fakültesi Dergisi, 1-27.

Akinboade, O. A., \& Makina, D. (2010). Econometric Analysis of Bank Lending and Business Cycles in South Africa. Applied Economics, 42(29), 3803-3811. doi:10.1080/00036840802360138

Akinlo, A. E., \& Oni, I. O. (2015). Determinants of Bank Credit Growth in Nigeria 1980-2010. European Journal of Sustainable Development, 4(1), 23. doi:10.14207/ejsd.2015.v4n1p23

Alper, C. E., Berument, M. H., \& Malatyali, N. K. (2001). The Effect of the Disinflation Program on the Structure of the Turkish Banking Sector. Russian \& East European Finance and Trade, 37(6), $81-95$.

Arsène, M. F., \& Guy-Paulin, D. D. (2013). An Econometric Analysis of the Nexus between Credit to the Private Sector, Inflation and Economic Growth: Case of Cameroon 1965-2010. Global Journal of Management and Business Research Interdisciplinary, 40-53.

Arslan, İ. ve Yapraklı, S. (2008). Banka Kredileri ve Enflasyon Arasındaki İlişki: Turkey Üzerine Ekonometrik Bir Analiz (1983-2007). İstanbul Üniversitesi İktisat Fakültesi Ekonometri ve İstatistik Dergisi, 7, 88-103.

Asongu, S. A. (2012). Financial Determinants of Consumerpriceinflation. What Do Dynamics in Money, Credit, Efficiencyand Size Tell Us?. African Governance and Development Institute, AGDI Working Paper, WP/12/019, 1-25.

Atta-Mensah, J. and Dib, A. (2008). Bank Lending, Credit Shocks, and the Transmission of Canadian Monetary Policy. International Review of Economics \& Finance, 17(1), 159-176. doi:10.1016/j.iref.2006.06.003

BDDK, Tekdüzen Hesap Planı ve İzahnamesi Hakkında Tebliğ, 23.12.2014, http://www.bddk.org.tr/WebSitesi/turkce/Mevzuat/Bankacilik_Kanununa_Iliskin_Duzenlemeler/16 52banka_thp_23_12_14.pdf

Begeç, E. (2015). Yurtiçi Kredi Hacmindeki Değişimlerin Makroekonomik Büyüklüklere Etkisi: Turkey Örneği, Adnan Menderes Üniversitesi Sosyal Bilimler Enstitüsü İktisat Anabilim Dalı Yüksek Lisans Tezi.

Bikker, J. (2004). Competition and Efficiency in a Unified European Banking Market. Edward Elgar Publishing.

Bitzis, G., Paleologos, J. M., \& Papazoglou, C. (2008). The Determinants of the Greek Current Account Deficit: The EMU Experience. Journal of International and Global Economic Studies, $1(1), 105-122$.

Bilgin, M. H., \& Kartal, F. (2009). Turkey'de Enflasyon ve Bankac1lık Sektörü Kredileri: 2002-2008 Dönemi Üzerine Bir İnceleme. Maliye Finans Yazıları, 1(85), 65-78.

Boyd, J. H., Levine, R., \& Smith, B. D. (2001). The Impact of Inflation on Financial Sector Performance. Journal of monetary Economics, 47(2), 221-248. doi:10.1016/S0304-3932(01)00049$\underline{6}$

Calza, A., \& Sousa, J. (2006). Output and Inflation Responses to Credit Shocks: Are There Threshold Effects in the Euro Area?. Studies in Nonlinear Dynamics \& Econometrics, 10(2). doi:10.2202/1558-3708.1253

Davis, J. S., Mack, A., Phoa, W., \& Vandenabeele, A. (2016). Credit Booms, Banking Crises, and the Current Account. Journal of International Money and Finance, 60, 360-377. doi:10.1016/j.jimonfin.2015.09.008

Dücan, E., Atay Polat, M. ve Balcığlu, E. (2016). Tüketim Toplumu Örneği Olarak Turkey'nin Cari Açık ve Tüketici Kredileri İlişkisi, Siyaset, Ekonomi ve Yönetim Araştırmaları Dergisi, 4(1), 161 188. 
Engle, R. and Granger, C. (1987). Co-integration and Error Correction: Representation, Estimation, and Testing. Econometrica: Journal of the Econometric Society, 251-276. doi:10.2307/1913236

Eslamloueyan, K. and Darvishi, A. (2007). Credit Expansion and Inflation in Iran: An Unrestricted Error Correction Model. Iranian Economic Review, 19, 105-126.

Gambetti, L. and Musso, A. (2012). Loan Supply Shocks and The Business Cycle. European Central Bank, Working Paper Series, No.1469, 1-57.

Geanakoplos, J. and Dubey, P. (2010). Credit Cards and Inflation, Games and Economic Behavior, 70(2), 325-353. doi:10.1016/j.geb.2010.02.004

Göçer, İ., Mercan, M. ve Peker, O. (2013). Kredi Hacmi Artisinin Cari Açığa Etkisi: Çoklu Yapısal Kırılmalı Eşbütünleşme Analizi, Ekonometri ve Istatistik Dergisi, 18, 1-17.

Groen, J. (2004). Corporate Credit, Stock Price Inflation and Economic Fluctuations. Applied Economics, 36(18), 1995-2006. doi:10.1080/0003684042000258251

Haight, A.D. (2007). Keynesian Angle for the Taylor Rule: Mortgage Rates, Monthly Payment Illusion, and the Scarecrow Effect of Inflation. Journal of Post Keynesian Economics, 30(2), 259277 doi:10.2753/PKE0160-3477300206

Hoshi, T., Kashyap, A., \& Scharfstein, D. (1991). Corporate Structure, Liquidity, and Investment: Evidence from Japanese Industrial Groups. The Quarterly Journal of Economics, 33-60. doi: $10.2307 / 2937905$

Huy Vu, N. (2010). What Credit Growth Tells About Inflation? An Empirical Study of Denmark, Norway and Sweden. The Royal Institute on Technology Sweden.

Hülsewig, O., Mayer, E., \& Wollmershäuser, T. (2009). Bank Behavior, Incomplete Interest Rate Pass-through, and the Cost Channel of Monetary Policy Transmission. Economic Modelling, 26(6), 1310-1327. doi:10.1016/j.econmod.2009.06.007

Kaya, Y.T. ve Doğan, E. (2005). Dezenflasyon Sürecinde Türk Bankacıllk Sektöründe Etkinliğin Gelişimi. Bankacılık Düzenleme ve Denetleme Kurumu, ARD Çalışma Raporları, 10(7).

Kessel, R. A., \& Alchian, A. A. (1962). Effects of Inflation. The Journal of Political Economy, 521537. doi: $10.1086 / 258714$

Kılıç, C. (2015). Tüketici Kredileri ve Cari Açık Arasındaki İlişki: Turkey Örneği. Atatürk Üniversitesi İktisadi ve İdari Bilimler Dergisi, 29(2), 407-420.

K1lıç, F. (2015). Bireysel Kredilerin Enflasyon Üzerindeki Etkisi: Turkey Örneği. Çanakkale Onsekiz Mart Üniversitesi Sosyal Bilimler Enstitüsü İktisat Anabilim Dalı Yüksek Lisans Tezi.

Korkmaz, S. (2015). Impact of Bank Credits on Economic Growth and Inflation. Journal of Applied Finance \& Banking, 5(1), 57-69.

Kunieda, T., \& Shibata, A. (2005). Credit Constraints and the Current Account: A Test for the Japanese Economy. Journal of International Money and Finance, 24(8), 1261-1277. doi:10.1016/j.jimonfin.2005.08.013

Mercan, M. (2013). Kredi Hacmindeki Değişimlerin Ekonomik Büyümeye Etkisi: Turkey Ekonomisi İçin Sınır Testi Yaklaşımı. Bankacılar Dergisi, 84, 54-71.

Moinescu, B. G. (2012). Credit Flow, Output Gap and Inflation: Nominal Convergence Challenges for the EU New Member States. Journal of Applied Quantitative Methods, 7(4), 1-10.

Moral-Benito, E., \& Roehn, O. (2016). The Impact of Financial Regulation on Current Account Balances. European Economic Review, 81, 148-166. doi:10.1016/j.euroecorev.2015.07.005

Motonishi, T., \& Yoshikawa, H. (1999). Causes of the Long Stagnation of Japan during the 1990s: Financial or Real?. Journal of the Japanese and International Economies, 13(3), 181-200. doi:10.1006/jjie.1999.0429 
Ngerebo-A, T.A. (2016). Monetary Policy and Inflation in Nigeria. International Journal of Finance and Accounting, 5(2), 67-76.

Pool, S., De Haan, L., \& Jacobs, J. P. (2015). Loan Loss Provisioning, Bank Credit and the Real Economy. Journal of Macroeconomics, 45, 124-136. doi:10.1016/j.jmacro.2015.04.006

Tang, T.C. (2001). Bank Lending and Inflation in Malaysia: Assessment from Unrestricted ErrorCorrection Models. Asian Economic Journal, 15(3), 275-289. doi:10.1111/1467-8381.00134

Telatar, E. (2011). Turkey'de Cari Açık Belirleyicileri ve Cari Açık-Krediler İlişkisi. Bankacılar Dergisi, 78, 22-34.

Tinoco-Zerme-o, M. Á., Venegas-Martínez, F., \& Torres-Preciado, V. H. (2014). Growth, Bank Credit, and Inflation in Mexico: Evidence from an ARDL-bounds Testing Approach. Latin American Economic Review, 23(1), 1.

Tiryaki, G. (2014). Turkey'de Bireysel Kredilerin Ekonomik Büyüme ve Cari Açık ile İlişsisi. Bankac1lar Dergisi, 91, 55-74.

Toda, H. and Yamamoto, T. (1995). Statistical Inference in Vector Autoregressions with Possibly Integrated Processes. Journal of Econometrics, 66(1), 225-250. doi:10.1016/0304-4076(94)01616-8

Yüksel, S. (2016). Turkey'de Cari İşlemler Açı̆̆ının Belirleyicileri: Mars Yöntemi ile Bir İnceleme. Bankacılar Dergisi, 96, 102-121.

Ziramba, E. (2008). Bank Lending, Expenditure Components and Inflation in South Africa: Assessment from Bounds Testing Approach. South African Journal of Economic and Management Sciences, 11(2), 217-228. doi:10.4102/sajems.v11i2.310 